\title{
PCR techniques applied to Hematodinium spp. and Hematodinium-like dinoflagellates in decapod crustaceans
}

\author{
Darryl A. Hudson, Robert D. Adlard \\ Department of Parasitology, The University of Queensland, Brisbane, Queensland 4072, Australia
}

\begin{abstract}
The amount of DNA recovered from $1 \times 10^{6}$ cells of Hematodinium-like dinoflagellates from Chionoecetes bairdi was $75 \mathrm{ng}$. PCR (polymerase chain reaction) amplification products were created from the host and Hematodinium spp. Amplified products of 680 base pairs (bp) were produced from Hematodinium-like dinoflagellates from $C$. bairdi for DNA concentrations of 100,50,20, 10 and $1 \mathrm{ng} \mathrm{Hl}^{-1}$ This amplified fragment was produced only from host tissue infected with the parasite. The lowest detectable limit of $1 \mathrm{ng}$ of DNA from Hematodinium-like sp. from $C$. bairdi corresponded to $1.0 \times 10^{4}$ cells. Diagnostic bands of $680 \mathrm{bp}$ were produced from Hematodinium spp. and Hematodinium-like spp. isolated from the following hosts: Chionoecetes opilio, Callinectes sapidus, Nephrops norvegicus and Portunus pelagicus. Host DNA (C. bairdi) produced a faint band of 1300 bp for con-

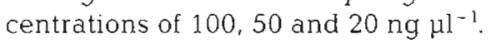

KEY WORDS: PCR · Dinoflagellate Hematodinium - Decapod

\section{INTRODUCTION}

Hematodinium spp. are parasitic dinoflagellates that infect the hemolymph of predominantly decapod crustaceans in many parts of the world. Hematodinium spp. have been reported from several commercially important host species, including the portunid blue crab Callinectes sapidus (Newman \& Johnson 1975), the cancer crabs Cancer irroratus and $C$. borealis (MacLean \& Ruddell 1978), the majid Tanner crabs Chionoecetes bairdi and C. opilio (Meyers et al. 1987, Meyers 1990), the Norway lobster Nephrops norvegicus (Field et al. 1992), the portunid sand crab Portunus pelagicus (Shields 1992, Hudson \& Shields 1994) and the portunid mud crab Scylla serrata (Hudson \& Lester 1994). Hematodinium-like dinoflagellates cause Bitter Crab Disease (BCD) in C. bairdi and C. opilio (Meyers et al. 1987, Meyers 1990) and 'watery flesh' in N. norvegicus (Field et al. 1992); both of these conditions make their flesh unmarketable.

Gross signs of high intensity Hematodinium spp. infections are characterized by a milky-white appearance of the hemolymph and/or an abnormal coloura- tion of the body (Meyers et al. 1987, Field et al. 1992, Hudson \& Shields 1994). Milder infections can be diagnosed by microscopical examination. In this study we attempt to diagnose the presence of Hematodinium spp. using the polymerase chain reaction (PCR), and to determine empirically the minimum level of infection that can be detected by this method.

\section{MATERIALS AND METHODS}

Sample collection. Sand crabs Portunus pelagicus were collected in March 1992 from Moreton Bay, Queensland, Australia. Norway lobsters Nephrops norvegicus were collected in January 1993 from the Firth of Clyde on the west coast of Scotland, UK. Blue crabs Callinectes sapidus were collected in January and November 1993 from the Rappalamoda River, Chesapeake Bay, Virginia, USA. Tanner crabs Chionoecetes bairdi and $C$. opilio were collected in February 1993 near Juneau and Dutch Harbor, Alaska, USA, respectively. Hematodinium australis from Portunus pelagicus were frozen at $-60^{\circ} \mathrm{C}$. Hemolymph samples 
from $C$. bairdi, $C$. opilio and $N$. norvegicus containing Hematodinium-like dinoflagellates were collected via syringe and fixed directly in $100 \%$ ethanol. Hematodinium-infected testes from $C$. sapidus were fixed directly in $100 \%$ ethanol and were shaken to produce the sediment that contains the Hematodinium sp. cells. Uninfected testes from $C$. bairdi were fixed directly in $100 \%$ ethanol. Hematodinium spp. were identified using light and electron microscopy (Meyers et al. 1987, Field et al. 1992, Shields 1992, Hudson \& Lester 1994, Hudson \& Shields 1994)

DNA extraction and purification. Initial Hematodinium spp. cell counts were determined using a hemocytometer Preparation of Hematodinium spp. required centrifugation of $250 \mu \mathrm{l}$ of ethanol-fixed infected hemolymph at $1600 \times \mathrm{g}$ for $3 \mathrm{~min}$; the pelleted cells were retained. Approximately $4 \mathrm{~mm}^{3}$ of ethanolfixed testes was used as the source of host DNA. DNA extraction for parasite cells and host testes required suspension in $500 \mu \mathrm{l}$ of extraction buffer $(50 \mathrm{mM}$ Tris, $5 \mathrm{mM}$ EDTA, $100 \mathrm{mM} \mathrm{NaCl}, \mathrm{pH} \mathrm{8),} 200$ ul of 10\% SDS and $20 \mu \mathrm{l}$ of proteinase-K (10 $\left.\mu \mathrm{g} \mathrm{mi}^{-1}\right)$ and incubation for 18 to $24 \mathrm{~h}$ at $56^{\circ} \mathrm{C}$. Samples were centrifuged at $1600 \times g$ for $15 \mathrm{~min}$ and the lysates transferred to clean tubes. DNA was purified using phenol/chloroform and was then precipitated in cold ethanol $(100 \% \mathrm{EtOH}$, $0.2 \mathrm{M} \mathrm{NaCl}$ ). Dried DNA was resuspended in $100 \mu \mathrm{l}$ of sterile deionised water. The DNA concentrations were determined using a spectrophotometer for both host and Hematodinium-like dinoflagellates from Chionoecetes bairdi.

DNA amplification. The first internal transcribed spacer (ITS1) of ribosomal DNA and flanking 3' end of the small subunit (SSU) was amplified by the PCR using oligonucleotide primers A (forward primer: 5' GTT CCC CTT GAA CGA GGA ATT C) and B (reverse primer: 5' CGC ATT TCG CTG CGT TCT TC). Primer A was located approximately 230 base pairs (bp) upstream of the 3' end of the SSU/ITS1 boundary, while primer $\mathrm{B}$ was located in the $5.8 \mathrm{~S}$ region. Primers were designed on conserved regions after alignment of published sequences available through GenBank. PCR amplifications were performed on known DNA concentrations of Chionoecetes bairdi and its Hematodinium-like dinoflagellates (Table 1) and on Hematodinium spp. from $C$. opilio, Callinectes sapidus, Portunus pelagicus and Nephrops norvegicus. PCR reactions were performed in $50 \mu l$ total reaction volume by adding $5 \mu$ l of $10 \times$ reaction buffer [final concentration $67 \mathrm{mM}$ Tris- $\mathrm{HCl}$, pH 8.8, $16.6 \mathrm{mM}$ $\left(\mathrm{NH}_{4}\right)_{2} \mathrm{SO}_{4}, 1 \mathrm{mM} \beta$-mercaptoethanol, $6.7 \mu \mathrm{M}$ EDTA, $0.15 \%$ Triton X-100, $200 \mu \mathrm{g} \mathrm{\mu l} \mathrm{l}^{-1}$ gelatin], $5 \mu \mathrm{MgCl}_{2}$ (final concentration $2 \mathrm{mM}$ ), $3 \mu$ l each of dNTP's (final concentration $200 \mu \mathrm{M}), 2$ ul each of forward and reverse primers (final concentration $2 \mathrm{ng} \mathrm{\mu l}^{-1}$ ), volume of target DNA to approximately 50 ng, 3 units of Taq polymerase (Bresatec) and sterile deionized water to a final volume of $50 \mu \mathrm{l}$. The reactions were mixed briefly and overlaid with $30 \mathrm{\mu l}$ of mineral oil. Cycling parameters were as follows: denaturation at $94^{\circ} \mathrm{C}$ for $60 \mathrm{~s}$, primer annealing at $55^{\circ} \mathrm{C}$ for $30 \mathrm{~s}$, chain extension at $72^{\circ} \mathrm{C}$ for $90 \mathrm{~s}$, with a total of 30 cycles; then a final extension cycle of $94^{\circ} \mathrm{C}$ for $60 \mathrm{~s}, 55^{\circ} \mathrm{C}$ for $30 \mathrm{~s}$ and $72^{\circ} \mathrm{C}$ for $7 \mathrm{~min}$. Each amplification product was electrophoresed through a $1.5 \%$ agarose gel (ethidium bromide stain, bromophenol blue marker dye) for 30 min at $100 \mathrm{~V}$. The gel was visualized under UV light and photographed.

\section{RESULTS AND DISCUSSION}

The purity of the Hematodinium-like dinoflagellates from the hemolymph of Chionoecetes bairdi was $99 \%$ after microscopical examination. The amount of DNA recovered from Hematodinium-like dinoflagellates from $C$. bairdi was $75.0 \mu \mathrm{g}$ from $1.0 \times 10^{6}$ cells. This amount was higher than that recovered by Eaton et al. (1991), i.e. $30 \mu \mathrm{g}$ of DNA from $1.0 \times 10^{6}$ cells of Hematodinium-like dinoflagellates from the same host.

Results of PCR amplification showed that both host and parasite were amplified using the primers described, but the product of $680 \mathrm{bp}$ in length was unique to Hematodinium $\mathrm{sp}$. Furthermore, the intensity of products derived from host DNA was much lower than that from the parasite. Amplification of Hematodinium-like dinoflagellates from Chionoecetes bairdi resulted in a diagnostic band at DNA concentrations of at least $1 \mathrm{ng} \mathrm{l}^{-1}$ (Fig. 1). The intensities of these bands were

Table 1. DNA concentrations/combinations for Chionoecetes bairdi (host) and Hematodinium-like dinoflagellates for PCR reactions to determine sensitivity

\begin{tabular}{|ccc|}
\hline Sample & $\begin{array}{c}\text { Host conc. } \\
\left(\mathrm{ng} \mathrm{H}^{-1}\right)\end{array}$ & $\begin{array}{c}\text { Parasite conc. } \\
\left(\mathrm{ng} \mu \mathrm{l}^{-1}\right)\end{array}$ \\
\hline Control & 0 & 0 \\
1 & 0 & 100 \\
2 & 0 & 50 \\
3 & 0 & 20 \\
4 & 0 & 10 \\
5 & 0 & 1 \\
6 & 0 & 0.5 \\
7 & 0 & 0.1 \\
8 & 0 & 0.01 \\
9 & 100 & 0 \\
10 & 50 & 0 \\
11 & 20 & 0 \\
12 & 10 & 0 \\
13 & 1 & 50 \\
14 & 50 & \\
\hline
\end{tabular}


Fig. 1. PCR products derived from Hematodinuum-like dinoflagellate from Chionoecetes bairdi. Lanes 1 \& 8: 100 bp molecular weight ladders; lane 2: C. bardi DNA concentration $100 \mathrm{ng} \mathrm{HI}^{-1}$; lanes 3 to 7: Hematodinum-like dinoflagellate DNA concentrations, 100, 50, 20, 10 and $1 \mathrm{ng} \mathrm{Il}^{-1}$, respectively

Fig. 2. PCR products derived from Hematodinum spp. Lanes 1 \& 8: $100 \mathrm{bp}$ molecular weight ladders; lane 2: Chionoecetes bairdi DNA concentration $100 \mathrm{ng} \mathrm{Hl}^{-1}$; lane 3: $50 \mathrm{ng} \mathrm{ll}^{-1}$ DNA from Chionoecetes bairdi and $50 \mathrm{ng} \mathrm{\mu l}^{-1}$ DNA from Hematodinium-like dinoflagellate; lanes 4 to 7 . unknown DNA concentrations of Hematodinium spp. from C. opilio, Callinectes sapidus, Nephrops norvegicus and Portunus pelagicus, respectively

similar for DNA concentrations of $100,50,20$ and $10 \mathrm{ng}$ $\mathrm{Hl}^{-1}$, but decreased significantly below these levels. Faint bands for the host $C$. bairdi were produced of 1300 bp (Figs. 1 \& 2, Lane 2) generated from DNA concentrations of 100,50 and $20 \mathrm{ng} \mu \mathrm{l}^{-1}$ but not observed at lower concentrations. The host/parasite combination produced the Hematodinium sp. band of $680 \mathrm{bp}$ and a band of 1300 bp for C. bairdi. The control (no DNA) PCR produced no bands. Short bands of $<100$ bp are nonspecific products and excess primer and can be removed by purification of the PCR products. These bands were not removed to ensure that a valid representation of the amplified fragments resulted.

Hematodinium spp. from the 3 other crab hosts and the lobster host also produced bands of $680 \mathrm{bp}$ (Fig. 2). However, the amplified product of $H$. australis from Portunus pelagicus was very faint, probably an indication of degraded DNA from the original sample rather than low levels because the initial cell count was $1.0 \times 10^{6}$ cells $\mathrm{ml}^{-1}$.

The PCR amplification using primers $A$ and $B$ can detect the presence of Hematodinium spp. from all hosts tested in this study, at a DNA amount of at least $1 \mathrm{ng}$. Based on cell counts, $1 \mathrm{ng}$ of DNA is equivalent to $1.3 \times 10^{4}$ cells. The diagnosis of non-host DNA is confirmed by the presence of a band of $680 \mathrm{bp}$ in length. The limiting factor is the amount of DNA present which can vary as a result of the extraction technique. For example, Eaton et al. (1991) required $3.3 \times 10^{4}$ cells of Hematodinium-like dinoflagellates from Chionoecetes bairdi to extract $1 \mathrm{ng}$ of DNA.

The production of an amplified product from the host/parasite DNA mix (Fig. 2) was significant because hemolymph from a potentially infected host can be sampled, DNA extracted and the diagnostic PCR per-
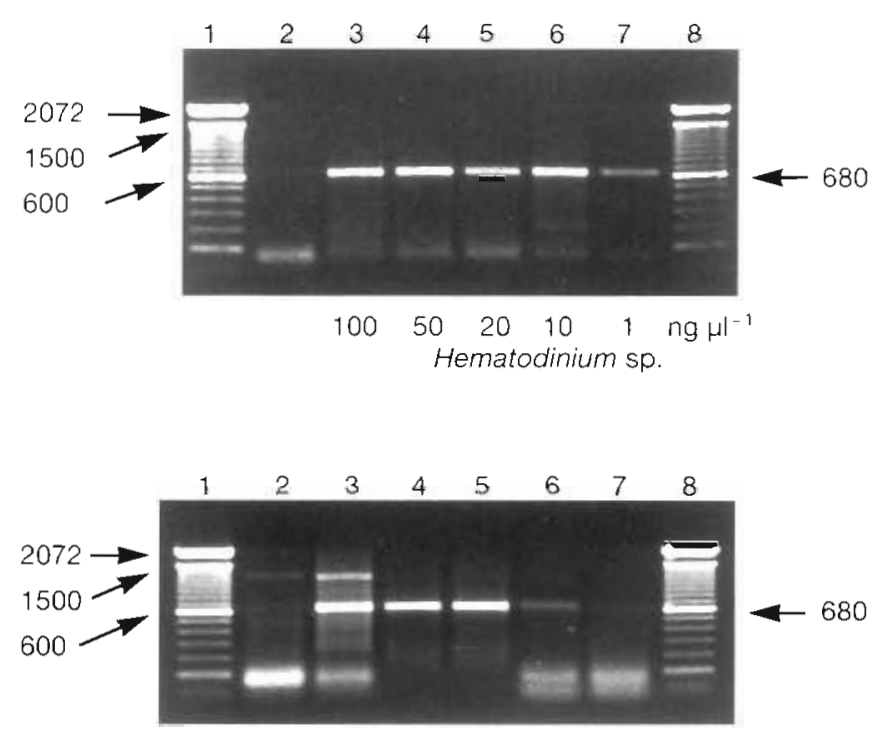

formed without isolation of the parasite. The host band of $1300 \mathrm{bp}$ acts as a positive control to verify the reaction parameters. It should be stressed that the primers used for this study are located in conserved regions and as such are not specific to Hematodinium spp. or other dinoflagellates. It is the length of the amplified product that is diagnostic, not simply the creation of a product. A positive test should be treated as diagnostic for the presence of non-host DNA; but, currently, microscopic examination should be undertaken prior to actual diagnosis of Hematodinium sp. However, in our opinion the power of PCR-based diagnostic tests is beyond question. Our continuing research is aimed at identifying regions of nucleotide sequence that are specific to 'species' or 'isolates' of Hematodinium spp. and Hematodinium-like dinoflagellates. This will provide sensitive and specific diagnosis of these organisms. Nevertheless, in order to determine nucleotide sequence and design more specific primers, the genome of Hematodinium spp. and Hematodiniumlike dinoflagellates must be first amplified and then sequenced. In this paper, we have described primers that will amplify the Hematodinium spp. and Hematodinium-like ribosomal DNA, even in the presence of host contaminants. This is an ongoing problem with DNA studies of all histozoic protozoa. Futhermore, sequence patterns in appropriate regions will provide a plethora of new 'characters' from which to infer phylogenetic relationships within this enigmatic group.

Acknowledgements. We thank Drs Rob Field, Ted Meyers and Sally Short, and Jeff Shields for providing us with samples of host and Hematodinium spp. from Scotland. Alaska and Virginia, respectively, We also thank 3 anonymous reviewers for their helpful criticism of the manuscript. 


\section{LITERATURE CITED}

Eaton, W. D., Love, D. C., Botelho, C., Meyers, T. R., Imamura, K., Koeneman, $T$ (1991). Preliminary results on the seasonality and life cycle of the parasitic dinoflagellate causing bitter crab disease in Alaskan Tanner crabs (Chionoecetes bairdi). J. invertebr. Pathol. 57: 426-434

Field, R. H., Chapman, C. J., Taylor, A. C., Neil, D. M., Vickerman, K. (1992). Infection of the Norway lobster Nephrops norvegicus by a Hematodinium-like species of dinoflagellate on the west coast of Scotland. Dis. aquat. Org. 13: $1-15$

Hudson, D. A., Lester, R. J. G. (1994). A parasitological survey of the mud crab Scylla serrata (Forskal) from southern Moreton Bay Queensland Australia. Aquaculture 120: $183-199$

Hudson, D. A., Shields, J. D. (1994). Hematodinium australis n. sp., a parasitic dinoflagellate of the sand crab Portunus

Responsible Subject Editor: J. E. Stewart, Dartmouth, N.S., Canada pelagicus from Moreton Bay, Australia. Dis aquat. Org 19: $109-119$

MacLean, S. A., Ruddell, C. L. (1978). Three new crustacean hosts for the parasitic dinoflagellate Hematodinium perezi (Dinoflagellata: Syndinidae) J. Parasitol. 64(1): 158-160

Meyers, T. R. (1990). Diseases caused by protistans and metazoans. In: Kinne, O. (ed.) Diseases of marine animals, Vol. III. Biologische Anstalt Helgoland, Hamburg, p. 350-400

Meyers, T. R., Koeneman, T M., Botelho, C., Short, S. (1987) Bitter crab disease: a fatal dinoflagellate infection and marketing problem for Alaskan Tanner crabs Chionoe. cetes bairdi. Dis. aquat. Org. 3: 195-216

Newman, M. W., Johnson, C. A. (1975). A disease of blue crabs (Callinectes sapidus) caused by a parasitic dinoflagellate, Hematodinium sp. J. Parasitol. 63(3): 554-557

Shields, J. D. (1992). Parasites and symbionts of the crab, Portunus pelagicus, from Moreton Bay, Australia. J. crust. Biol. 12(1): $94-100$

Manuscript first received: May 5, 1994

Revised version accepted: August 16, 1994 